\title{
Determination of the Content of Hazardous Heavy Metals on Lycopersicon Esculentum Mill. Grown around a Contaminated Area
}

\author{
Napattaorn Buachoon
}

\begin{abstract}
The content of copper, lead, cadmium, and zinc on tissues of Lycopersicon esculentum Mill. grown around a contaminated area. Rhizomes showed a high content of the metals, followed by the leaves, and finally the stems, which had the lowest content of the metals. Lead concentrations in rhizomes, stems, leaves were $430 \mathrm{mg} / \mathrm{Kg}, 180 \mathrm{mg} / \mathrm{Kg}$, and 120 $\mathrm{mg} / \mathrm{Kg}$, respectively, while copper concentrations were 810 $\mathrm{mg} / \mathrm{Kg}, 463 \mathrm{mg} / \mathrm{Kg}$, and $250 \mathrm{mg} / \mathrm{Kg}$, respectively. In contrast, cadmium and zinc concentrations were lower and varied from $30 \mathrm{mg} / \mathrm{Kg}$ on rhizomes, $58 \mathrm{mg} / \mathrm{Kg}$ on leaves, and $46 \mathrm{mg} / \mathrm{Kg}$ on stems for cadmium, and the content of zinc found ranged from $31 \mathrm{mg} / \mathrm{Kg}$ on rhizomes, $35 \mathrm{mg} / \mathrm{Kg}$ on stems, and $42 \mathrm{mg} / \mathrm{Kg}$ on leaves. Soil concentrations were high in site 3 for lead and copper, 4,621 $\mathrm{mg} / \mathrm{Kg}$ and $5,631 \mathrm{mg} / \mathrm{Kg}$, respectively; lower concentrations were found for cadmium and zinc, $223 \mathrm{mg} / \mathrm{Kg}$ and $57 \mathrm{mg} / \mathrm{Kg}$, respectively. As expected, those sections which contained higher levels of heavy metals in the soil also showed to have higher heavy metal uptake by various parts of Lycopersicon esculentum Mill. These data demonstrate Lycopersicon esculentum Mill. ability to uptake copper and lead, and to some extent cadmium and zinc, from heavy metal contaminated soils.
\end{abstract}

Index Terms-Lycopersicon esculentum Mill., hazardous heavy metals, inductively coupled plasma-optical emission spectrometry.

\section{INTRODUCTION}

Global industrialization and human social and agricultural activities have an effect on environmental pollution and the global ecosystem. This corruption of the ecosystem has a negative effect on human health and on all living organisms. Growing industrialization and environmental pollution from technology have started to affect human health [1]. Air pollution is aesthetically offensive and can be a genuine health hazard to humans as well as to vegetation [2]. The level of environmental pollution in some areas of Turkey is alarmingly high and is a national problem. Air pollution is the most important problem in the main city centers.

Pollution of the environment with toxic metals has increased dramatically since the onset of the industrial revolution [3]. Soil pollution by heavy metals, such as cadmium, lead, chromium, and copper, etc. is a problem of concern. Although heavy metals are naturally present in soil, contamination and comes, from local sources: mostly industry (mainly non-ferrous industries, but also power

Manuscript received May 21, 2014; revised July 13, 2014.

Napattaorn Buachoon is with the Valaya Alongkorn Rajabhat University under Royal Patronage, Pathumtani Province, CO 13180 Thailand (e-mail: send2duang@hotmail.com). plants and iron, steel and chemical industries), agriculture (irrigation with polluted waters, sewage sludge and fertilizer, especially phosphates, contaminated manure and pesticide containing heavy metals), waste incineration, combustion of fossil fuels and road traffic. Long-range transport of atmospheric pollutants adds to the metals in the natural environment [4]. In recent years, it has been shown that lead levels in soil and vegetation have increased considerably due to traffic pollution, especially from usage of leaded petrol and exhaust combustion [5]-[8]. The problem worsens as daily traffic increases [9].

The industrial activity in the area has resulted in the accumulation of many heavy metals in the soil including copper, lead, cadmium, and zinc. The accumulation of these heavy metals in the soils, however, may have lessened over time as a result of the metals being up taken by creosote bushes. To date, no studies have been performed demonstrating creosote bushes as metal scavengers. Because creosote bushes are so prevalent throughout the southwest and because they are able to grow in such contaminated soil environments, they possess the qualities necessary for utilization as phytoremediation resources.

The aim of the present study is to determined of the content of hazardous heavy metals present in the individual tissues including the rhizomes, stems, leaves and the soils from which the plants grew. Three replicate samples were collected from various locations on the Pathumtani Province. The samples were oven dried and then the tissues of rhizomes, stems, and leaves were separated. The soil and tissue samples were acid digested and analyzed by Inductively Coupled Plasma-Optical Emission Spectrometry (ICP-OES) for the determination of the content of copper, lead, cadmium, and zinc.

\section{MATERIALS AND METHODS}

\section{A. Collection of Lycopersicon esculentum Mill.}

For the present study, Five locations were arbitrarily chosen to represent creosote bushes in various locations around the copper smelting industry. A six site, located 30 miles from sites 1-5, was chosen for control samples of the bushes. During the summer season of 2013, three replicate samples of creosote bushes, approximately $3 \mathrm{ft}$. high and of the same stage of maturity, were collected using a shovel. A diameter of approximately $2 \mathrm{ft}$. was dug around each bush. The bushes were pulled up by the rhizomes and the residual soils from the rhizomes were shaken off the bushes and collected in plastic containers for later analysis. All three 
bushes were combined for representative sampling purposes.

\section{B. Preparation of Lycopersicon esculentum Mill. and Soils}

Samples of creosote bushes from each site were oven dried at a temperature of $90^{\circ} \mathrm{C}$ for four days. This mild temperature was chosen to avoid vapor loss of the metals or of their salts. After drying, the rhizomes, stems, leaves were separated and ground.

Soils were also sieved to -100 Tyler mesh to remove unwanted rock and sediment materials from the matrix. After the tissues were obtained, three replicate one gram samples of each tissue were acid digested according to EPA method 3050. A fourth replicate sample was also prepared and digested but was spiked with either 1.0 or 5.0 ppm each of copper, lead, cadmium, and zinc, which were the metals of interest. A blank was also prepared to ensure the integrity of the analytical procedure. The EPA protocol that was adopted for the acid digestion of the soil and tissue samples here can be described as follows: A 1.00-2.00 gram homogenous representative sample was obtained and placed in conical beakers. Sample slurries were prepared by adding $10 \mathrm{ml}$ of 1:1 nitric acid $\left(\mathrm{HNO}_{3}\right)$. The slurries were then covered with watch glasses, heated to near boiling, and refluxed for 15 min. After refluxing, the slurries were cooled and then $5 \mathrm{ml}$ of concentrated $\mathrm{HNO}_{3}$ were added and the solution was again allowed to reflux for an additional $30 \mathrm{~min}$. This last step was repeated to ensure complete oxidation of the metals. After the third refluxing period, the sample was cooled to room temperature and $2 \mathrm{ml}$ of deionized water and up to $10 \mathrm{ml}$ of $30 \%$ hydrogen peroxide were added. The samples were then filtered to remove any particulates which might interfere with ICP-OES analysis. The filtrates were collected in $100 \mathrm{ml}$ volumetric flasks and were diluted with deionized water to volume. The samples, which were approximately $5.0 \%(\mathrm{v} / \mathrm{v})$ nitric acid, were now ready for ICP-OES analysis.

\section{Data Analysis}

The experiments were performed in triplicate, and the samples were analyzed in triplicate. For each set of given data, standard statistical methods were used to determine the mean values and standard deviations. Confidence intervals of $95 \%$ were calculated for each set of samples to determine the error margin.

\section{RESULTS}

The highest concentrations of heavy metals were found in samples from site 3. Site 3 Lead concentrations in rhizomes, stems, leaves were $430 \mathrm{mg} / \mathrm{Kg}, 180 \mathrm{mg} / \mathrm{Kg}$, and $120 \mathrm{mg} / \mathrm{Kg}$, respectively, while copper concentrations were $810 \mathrm{mg} / \mathrm{Kg}$, $463 \mathrm{mg} / \mathrm{Kg}$, and $250 \mathrm{mg} / \mathrm{Kg}$, respectively. In contrast, cadmium and zinc concentrations were lower and varied from $30 \mathrm{mg} / \mathrm{Kg}$ on rhizomes, $58 \mathrm{mg} / \mathrm{Kg}$ on leaves, and 46 $\mathrm{mg} / \mathrm{Kg}$ on stems for cadmium, and the content of zinc found ranged from $31 \mathrm{mg} / \mathrm{Kg}$ on rhizomes, $35 \mathrm{mg} / \mathrm{Kg}$ on stems, and $42 \mathrm{mg} / \mathrm{Kg}$ on leaves. Soil concentrations were high in site 3 for lead and copper, 4,621 $\mathrm{mg} / \mathrm{Kg}$ and $5,631 \mathrm{mg} / \mathrm{Kg}$, respectively; lower concentrations were found for cadmium and zinc, $223 \mathrm{mg} / \mathrm{Kg}$ and $57 \mathrm{mg} / \mathrm{Kg}$, respectively. In all of the samples, copper concentrations were the highest, followed by lead. Cadmium and Zinc concentrations were extremely low.

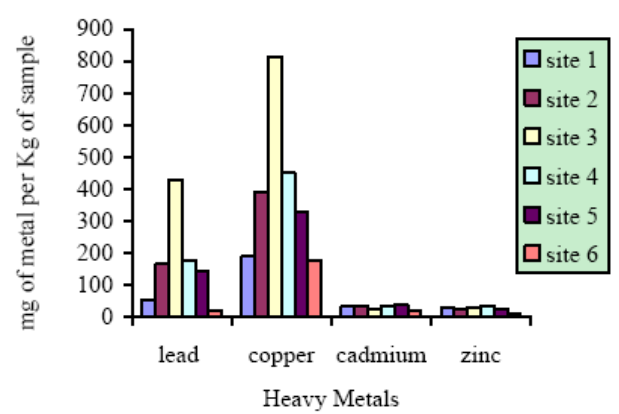

Fig. 1. Lead, copper, cadmium and zinc contamination in rhizomes where Lycopersicon esculentum Mill. (every data point represents the mean value of three replicate samples).

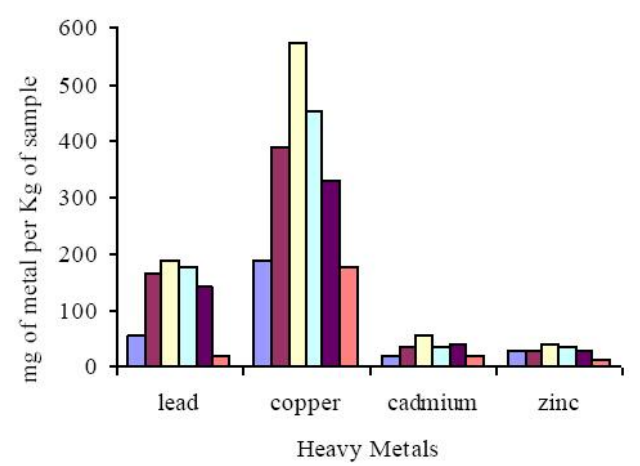

Fig. 2. Lead, copper, cadmium and zinc contamination in stems where Lycopersicon esculentum Mill. (every data point represents the mean value of three replicate samples).

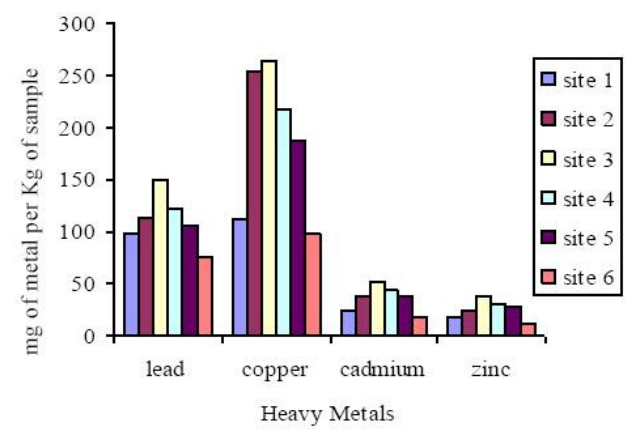

Fig. 3. Lead, copper, cadmium and zinc contamination in leaves where Lycopersicon esculentum Mill. (every data point represents the mean value of three replicate samples).

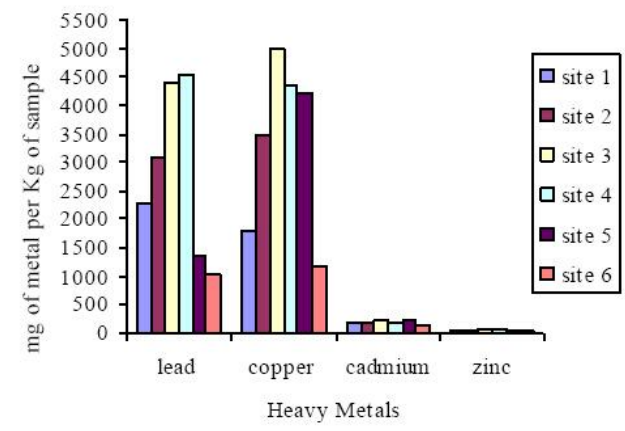

Fig. 4. Lead, copper, cadmium and zinc contamination in soil where Lycopersicon esculentum Mill. (every data point represents the mean value of three replicate samples).

Heavy metal concentrations for the rhizomes from which Lycopersicon esculentum Mill. grew are shown in Fig. 1. Plant tissue metal contents for stems, leaves and soil are reported in Fig. 2, 3, and 4, respectively. The total metal concentrations in soils and plants from each site were all 
nearly 100-fold higher than in the control samples (site 6).

As expected, those sections which contained higher levels of heavy metals in the soil also showed to have higher heavy metal uptake by the various parts of Lycopersicon esculentum Mill. The highest levels of heavy metals found in various tissues of creosote were in conflict with the expected values. Particularly, because site 1 was located within the closest proximity to the suspected contamination source, the anticipated data should have been much higher at that site.

Clearly, Lycopersicon esculentum Mill. takes up heavy metals from the soil. It is unclear though whether the plant has evolved to adapt to the high concentrations of heavy metals or if the bushes already possess the capability of being planted under these contaminated conditions and still grow to maturity [10]-[14]. Plants are known to have at least two defense mechanisms whereby they are able to incorporate metals into their tissues and continue to survive. In response to the toxic elements, plants can synthesize metalchelating proteins called metallothioneins [15]-[17]. Another mechanism which may account for the accumulation of heavy metals in plants is the synthesis of phytochelatins, as suggested by Rauser [18].

Various other mechanisms have also been suggested regarding where the heavy metals are compartmentalized. Plants can also tolerate heavy metal contaminates by excluding the metals from sensitive sites, changing the metabolic pathways to prevent damage, or by synthesizing enzymes that would detoxify the heavy metals. Detrimental effects of heavy metals on plants have also been found to prevent the uptake of valuable nutrients such as potassium and phosphorus. All of these parameters regarding the effects of heavy metals in relation to Lycopersicon esculentum Mill. will require further investigation [19], [20].

Further studies will involve utilizing appropriate analytical techniques to investigate the nature of the binding mechanism as well as the chemical functional groups responsible for the binding or uptake. For example, Environmental Scanning Electron Microscopy (ESEM) studies, in conjunction with X-ray Energy Dispersive Spectroscopy (EDS), will be undertaken to examine any noticeable morphological changes as a result of the incorporation of heavy metals in the tissues [21] of the creosote bush. The future investigation of examining the molecular and structural characteristics which control the metal ion affinity and specificity in creosote bushes will ultimately aid in establishing our ability to selectively modify the metal binding properties. As a result, the biomaterials' metal scavenging abilities can be substantially enhanced.

\section{CONCLUSIONS}

Creosote bush plants have succeeded in demonstrating the ability to uptake heavy metals such as copper and lead from contaminated soils. The metal concentrations in the plant are dispersed throughout the rhizomes, leaves, and stems with the highest concentration found in the rhizomes. As expected, the higher the contaminant soil concentration, the higher the metal uptake by the various parts of Lycopersicon esculentum Mill. These data demonstrate the potential of phytoremediation via creosote bush as a low-cost, effective means of removing heavy metals from contaminated soils. The nature of the chemical groups that are responsible for the binding of the metals, however, is not fully understood and will be the purpose of further investigation.

\section{ACKNOWLEDGEMENT}

The authors would like to thank you Valaya Alongkorn Rajabhat University under The Royal Patronage for the financial support of the present project.

\section{REFERENCES}

[1] K. YagdiI, O. Kacar, and N. Azkan, "Heavy metal contamination in soils and it's effects in agriculture," J. of Fac. of Agric., OM Ü, vol. 15, pp. 109-115, 2000

[2] J. Janick, Horticultural Science, 4th ed. Perdue University: W. H. Freeman and Company, p. 746. 1986.

[3] J. O. Nriagu, "Global inventory of natural and anthropogenic emissions of trace metals to the atmosphere," Nature, vol. 279, pp. 409-411, 1979.

[4] European Environmental Agency, Soil pollution by Heavy Metals, Europe's environment the Debris assessment, Luxembourg: Office des Publications, p. 676, 1995.

[5] F. Cabrera, L. Clemente, E. D. Barrientos, R. Lopez, and J. M. Murillo, "Heavy metal pollution of soil affected by the Guadiamar toxic flood," Sci. Total Environ., vol. 242, pp. 117-129, 1999.

[6] M. Vidal, J. F. Lopez-Sanchez, J. Sastre, G. Jimenez, T. Dagnac, R. Rubio, and G. Rauret, "Prediction of the impact of the Aznalcollar toxic spill on the trace element contamination of agricultural soils," Sci. Total Environ. vol. 242, pp. 131-148, 1999.

[7] P. Madejon, J. M. Murillo, T. Maranon, F. Cabrera, and Lopez, "Bioaccumulation of $\mathrm{As}, \mathrm{Cd}, \mathrm{Cu}, \mathrm{Fe}$ and $\mathrm{Pb}$ in wild grasses affected by the Aznalcollar mine spill(SW Spain)," Sci. Total Environ., vol. 290, pp. 105-120, 2002

[8] P. C. Onoanwa and J. O. Adoghe, "Heavy-Metal content of roadside gutter sediments in Ibadan,” Nigeria Environ Int., vol. 23, pp. 873-877, 1997.

[9] M. S. Oncel, V. Zedef, and S. Mert, "Lead contamination of roadside soils and plants in the highways between Istanbul and Sakarya, NW Turkey," Fresenius Environ. Bulletin, vol. 13, pp. 1525-1529, 2004.

[10] E. Cortes, H. A. Das, D. A. Tarafdar, and B. A. Vasconcellos, "Toxic heavy Metals and other Trace Elements in Foodstuff from 12 different countries," Biological Trace Element Research, vol. 20, pp. 415-422, 1994.

[11] FAO/WHO, "Evaluation of certain food additives and contaminants," Report of the joint FAO / WHO Expert Committee of Food Additives, WHO Technical Rep. Ser., no. 631, pp. 11-17, 1978.

[12] W. H. O. Ernst, J. A. Verkleij, and H. Schat, "Metal tolerance in plants," Bot. Neerl, vol. 41, no. 3, pp. 229-248, 1992.

[13] A. H. Khan, S. A. Trafdar, and M. Ali et al., "The status of trace and minor trace elements in some Bangladeshi Foodstuff," $J$. of Radiologocal and Nuclear Chem., vol. 134, pp. 367-381, 1989.

[14] T. M. Krishnamoorty and R. M. Tripathi, "Measurements and modeling in environmental pollution," BARC News Letter, India, vol. 176, pp. 3-12, 1998.

[15] M. Vojtechova and S. Leblova, "Uptake of lead and cadmium by maize seedlings and the effect of heavy metals on the activity of phosphoenolpyruvate carboxylase isolated from maize," Biologia Plantarum (PRAHA), vol. 33, no. 5, pp. 386-394, 1991.

[16] P. Ostapczuk, P. Valenta, H. Rutzel, and H. W. Nurnberg, "Determination of heavy metal in environmental samples," Sci. of Total Environ, vol. 60, pp. 1-16, 1987.

[17] P. S. Sastry and B. R. Chaudhary, "Fixation of $\mathrm{CO}_{2}$ and incorporation of thymidine under heavy metal stress in Closterium moniliferum," Folia Microbiol, vol. 34, pp. 106-111, 1989.

[18] R. D. Worthington, "Effects of El Paso pollutants on the lichen, moss, and winter annual flora on andesite rock formations," in Environmental Hazards and Bioresource Management in the United States-Mexico Borderlands, P. Gangster and H. Walter, Eds. UCLA Latin American Center Publications, Los Angeles, 1989, pp. 105-115.

[19] R. Kastori, M. Petrovic, and N. Petrovic, "Effect of excess lead, cadmium, copper, and zinc on water relations in sunflowers," J. Plant Nutr., vol. 15, no. 11, pp. 2427-2439, 1992.

[20] S. Sanglimsuwan et al., "Resistance to and uptake of heavy metals in mushrooms," J. Ferment. Bioeng., vol. 75, no. 2, pp. 112-114, 1993. 
[21] M. Schuhmacher, J. L. Domingo, and J. Corbella, "Dietary intake of Copper, Choromium and Zinc in Tarrangona Province," Spain. Sci. of Total Environ., vol. 132, pp. 3-10, 1983.

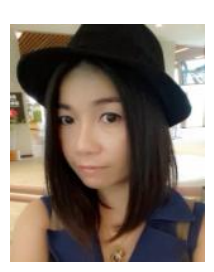

Napattaorn Buachoon was born on November 30, 1979. She got her bachelor's degree in general science from the Department of Education, Faculty of Education, Valaya Alongkorn Rajabhat University under the Royal Patronage, Pathumtani, Thailand in 2001. She got her master's degree in science education from the Department of Science Education Faculty of Science and Technology, Valaya Alongkorn Rajabhat University under the Royal Patronage, Pathumtani, Thailand in 2003.
She is a lecturer in the Department of Science Education, Faculty of Science and Technology, Valaya Alongkorn Rajabhat University under the Royal Patronage, Klongluang, Pathumtani, Thailand. Her special expertise is analytical chemistry. 